University of Nebraska - Lincoln

DigitalCommons@University of Nebraska - Lincoln

USGS Staff -- Published Research

US Geological Survey

1997

Radiocarbon Ages and Environments of Deposition of the Wono and Trego Hot Springs Tephra Layers in the Pyramid Lake Subbasin, Nevada

Larry Benson

University of Colorado at Boulder, great.basin666@gmail.com

Joseph P. Smoot

U.S. Geological Survey

Michaele Kashgarian

Lawrence Livermore National Laboratory

Andrei Sarna-Wojcicki

U.S. Geological Survey

James W. Burdett

U.S. Geological Survey

Follow this and additional works at: http://digitalcommons.unl.edu/usgsstaffpub

Benson, Larry; Smoot, Joseph P.; Kashgarian, Michaele; Sarna-Wojcicki, Andrei; and Burdett, James W., "Radiocarbon Ages and Environments of Deposition of the Wono and Trego Hot Springs Tephra Layers in the Pyramid Lake Subbasin, Nevada" (1997). USGS Staff -- Published Research. 794.

http:// digitalcommons.unl.edu/usgsstaffpub/794

This Article is brought to you for free and open access by the US Geological Survey at DigitalCommons@University of Nebraska - Lincoln. It has been accepted for inclusion in USGS Staff -- Published Research by an authorized administrator of DigitalCommons@University of Nebraska - Lincoln. 


\title{
Radiocarbon Ages and Environments of Deposition of the Wono and Trego Hot Springs Tephra Layers in the Pyramid Lake Subbasin, Nevada
}

\author{
Larry V. Benson \\ U.S. Geological Survey, 3215 Marine Street, Boulder, Colorado 80303-1066 \\ Joseph P. Smoot \\ U.S. Geological Survey, MS 955, Reston, Virginia 22092 \\ Michaele Kashgarian \\ Lawrence Livermore National Laboratory, P.O. Box 808, L-397, Livermore, California 94550 \\ Andrei Sarna-Wojcicki \\ U.S. Geological Survey, MS 975, 345 Middlefield Road, Menlo Park, California 94025 \\ and \\ James W. Burdett \\ U.S. Geological Survey, MS 963, Denver Federal Center, Lakewood, Colorado 80225
}

Received August 13, 1996

\begin{abstract}
Uncalibrated radiocarbon data from core PLC92B taken from Wizards Cove in the Pyramid Lake subbasin indicate that the Trego Hot Springs and Wono tephra layers were deposited 23,200 \pm 300 and $27,300 \pm 300{ }^{14} \mathrm{C}$ yr B.P. (uncorrected for reservoir effect). Sedimentological data from sites in the Pyramid Lake and Smoke Creek-Black Rock Desert subbasins indicate that the Trego Hot Springs tephra layer was deposited during a relatively dry period when Pyramid Lake was at or below its spill point $(1177 \mathrm{~m})$ to the Winnemucca Lake subbasin. The Wono tephra layer was deposited when lake depth was controlled by spill across Emerson Pass sill $(1207 \mathrm{~m})$ to the Smoke Creek-Black Rock Desert subbasin. ${ }^{18} \mathrm{O}$ data from core PLC92B also support the concept that the Trego Hot Springs tephra fell into a relatively shallow Pyramid Lake and that the Wono tephra fell into a deeper spilling lake. (1) 1997 University of Washington.
\end{abstract}

\section{INTRODUCTION}

Tephra layers can serve as valuable time-stratigraphic markers if their ages can be accurately determined and if the layers possess unique chemical compositions. The Wono and Trego Hot Springs (THS) tephra layers, first described by Davis (1978), possess unique chemical compositions and are found exposed in lacustrine sediments throughout the northwestern Great Basin. In his pioneering work on the Quaternary tephra layers of the Lahontan Basin, Davis (1978) named the Wono layer for its exposure along the shore of Pyramid Lake, immediately east of Pyramid Island (Wono, which means cone-shaped basket, is the Paiute name for the island). Davis designated an exposure at Agency Bridge Nixon, Nevada, as the type locality of the Wono layer and he designated an exposure near Trego Hot Springs, in the Black Rock Desert, as the type locality of the THS layer (Fig. 1).

Several attempts have been made to date the Wono and THS layers. Davis (1983) assigned an age of $24,800{ }^{14} \mathrm{C}$ yr to the Wono layer based on the ${ }^{14} \mathrm{C}$ age $(24,480 \pm 430 \mathrm{yr}$ B.P.) of a wood sample (Tx-2338) that lay $0.1 \mathrm{~m}$ above this layer at the Popcorn Rocks locality (Fig. 1). At the Pyramid Island locality (Fig. 1), the THS layer is located $\sim 0.4 \mathrm{~m}$ above the Wono layer. In order to estimate the age of this layer, Davis (1983) used the estimated ${ }^{14} \mathrm{C}$ age of the Wono layer, the ${ }^{14} \mathrm{C}$ age of a wood sample $(33,650 \pm 1720 \mathrm{yr}$ B.P., Tx-2542) located $3.2 \mathrm{~m}$ below the THS layer, and the ${ }^{14} \mathrm{C}$ age of an organic-rich sample $(29,000 \pm 980 \mathrm{yr}$ B.P., Tx2596) located $1.6 \mathrm{~m}$ below the THS layer to calculate a linear sedimentation rate of $0.28 \mathrm{~m} / 10^{3} \mathrm{yr}$ at the Pyramid Island site. He applied this sedimentation rate to the interval 


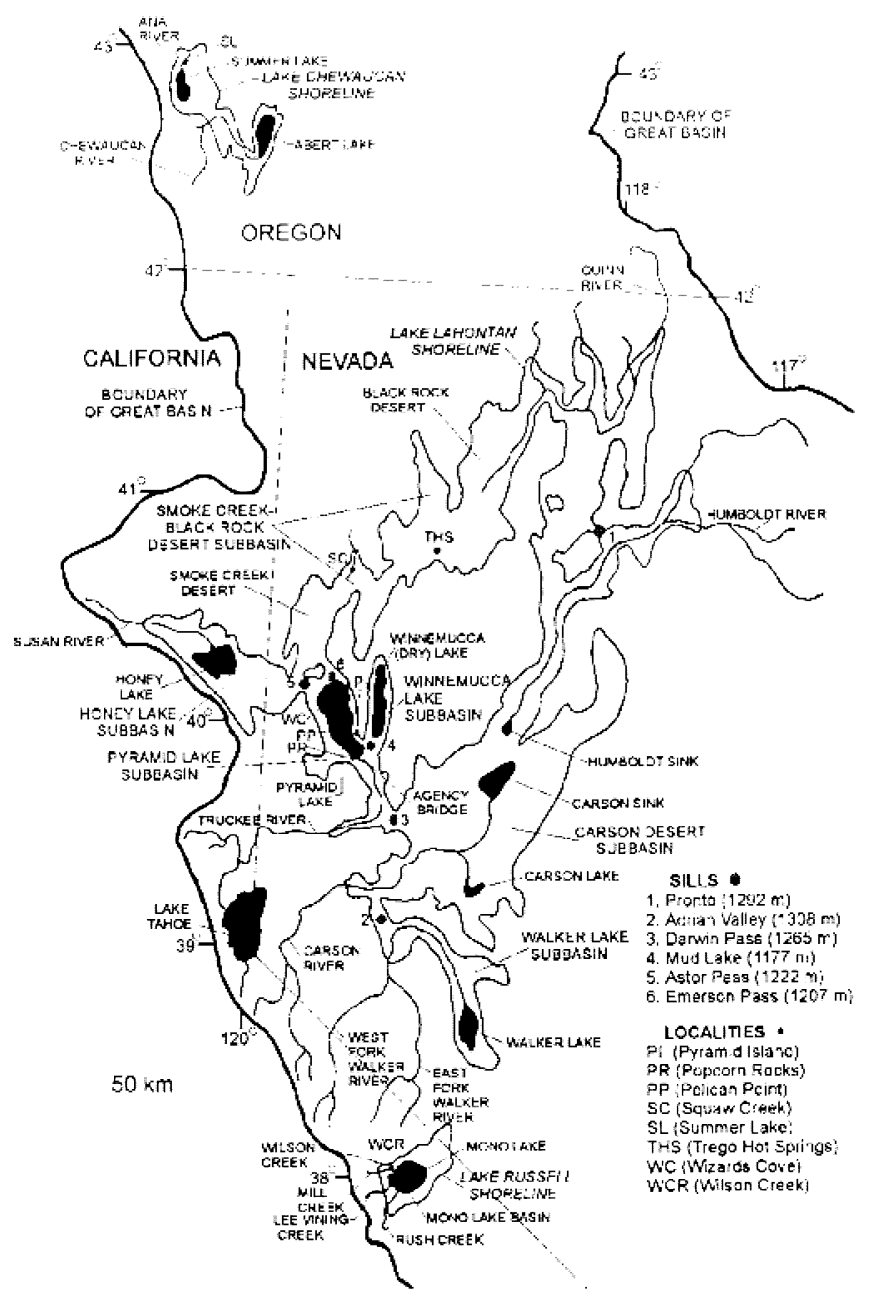

FIG. 1. Map of the western part of the Great Basin showing localities discussed in this paper.

separating the Wono and THS tephra layers to assign an age of $23,400 \pm 430{ }^{14} \mathrm{C}$ yr B.P. ${ }^{1}$ to the THS layer.

Berger (1992), using a thermoluminescence technique, obtained an age of $24,300 \pm 2000 \mathrm{yr}$ for the THS tephra [which converts to $20,400 \pm 2000{ }^{14} \mathrm{C}$ yr using the data of Bard et al. (1990, 1993, 1996) and Edwards et al. (1993)]. Negrini and Davis (1992) correlated the paleosecular variation (PSV) record of Lake Chewaucan in south-central Oregon with the PSV record of a relatively well-dated sedimentary sequence (Wilson Creek formation) from the Mono Lake basin of east-central California (Fig. 1). From its position in the Chewaucan magnetic sequence, the THS layer was estimated to have a ${ }^{14} \mathrm{C}$ age of $21,800 \pm 1000 \mathrm{yr}$ B.P. ${ }^{2}$

\footnotetext{
${ }^{1}$ The statistical uncertainty in the ${ }^{14} \mathrm{C}$ data used in the age extrapolation actually ranged from 430 to $1720 \mathrm{yr}$.

${ }^{2}$ Radiocarbon age control for the Wilson Creek formation does not permit age estimation of PSV features with an accuracy of better than $1000 \mathrm{yr}$ (Benson et al., 1990, Fig. 15).
}

Davis (1983) used his estimated age of the THS layer and its stratigraphic position in sediments exposed in the Squaw Creek drainage, Nevada (Fig. 1), to estimate the level of Lake Lahontan at the time of deposition of the THS layer. The Smoke Creek-Black Rock Desert subbasin is separated from the Pyramid Lake/Winnemucca Lake subbasins by Emerson Pass sill $(1207 \mathrm{~m})$ which lies $49 \mathrm{~m}$ above the presentday (1997) elevation of Pyramid Lake $(1158 \mathrm{~m})$. Davis (1983) described two sites along the Squaw Creek drainage that contain the THS tephra layer. At the downstream (south) site, Davis believed that the THS layer was contained within the base of a delta at an elevation of $1256 \mathrm{~m}$; at the upstream site, Davis believed that the THS layer was contained within alluvium at an elevation of $1260 \mathrm{~m}$. These observations implied that, when the Trego tephra fell, the elevation of Lake Lahontan lay between 1256 and $1260 \mathrm{~m}$, indicating that Winnemucca Lake, Pyramid Lake, and the Smoke CreekBlack Rock Desert subbasins were connected by a single lake with a surface area of $\sim 6600 \mathrm{~km}^{2}$. In this paper, we present new information on the age and environment of deposition of the THS and Wono layers that indicate the surface of Pyramid Lake lay well below the Squaw Creek site when the Trego tephra layer was deposited. Our studies indicate that the surface elevation of Pyramid Lake was at or below its spill point to Winnemucca Lake subbasin (1177 $\mathrm{m}$ ) when the THS layer was deposited and was at its spill point to the Smoke Creek-Black Rock Desert subbasin $(1207 \mathrm{~m})$ when the Wono layer was deposited.

\section{METHODS}

In June 1992, Roger Byrne and Scott Mensing of the University of California-Berkeley and the senior author of this paper obtained a $17.35-\mathrm{m}$ core (PLC92B) in $7.1 \mathrm{~m}$ of water from the Wizard's Cove area of Pyramid Lake (Fig. 1) using a modified square-rod Livingstone corer. During coring, two tephra layers were noted at 5.07 and $7.90 \mathrm{~m}$ below the sediment-water interface. The 7.90-m-deep layer proved difficult to penetrate and the top $0.20 \mathrm{~m}$ of the 0.64 $\mathrm{m}$ cored interval below the oldest tephra layer was lost in the coring process.

To obtain glass shards from both tephra layers, samples were wet sieved with water in plastic sieves fitted with nylon screens, retaining the 100 - to 200 -mesh size fraction (80 to $150 \mu \mathrm{m})$. This size fraction was placed in an ultrasonic vibrator and treated with a $10 \%$ solution of $\mathrm{HCl}$ for a few minutes to remove carbonates adhering to the glass shards. The samples were subsequently treated with an $8 \%$ solution of HFL to remove other mineral coatings and altered glass surfaces. The shards were separated from other components of the tephra sample using a magnetic separator and heavy liquids, as per Sarna-Wojcicki et al. (1984). Polished shards were analyzed with an electron microprobe by C. E. Meyer of the 
U.S. Geological Survey for Si, Al, Fe, Mg, Mn, Ca, Ti, Na, and $\mathrm{K}$, and the results were statistically compared with the chemical compositions of $\sim 3600$ volcanic glasses from the western United States and adjacent Pacific Ocean. Correlations between unknown and known tephra layers were based on the chemical composition of the volcanic shards and relative stratigraphic position. The $5.07-\mathrm{m}$ tephra layer in PLC92B was identified as the THS layer and the 7.90-m layer was identified as the Wono layer (Table 1).

Age control for PLC92B is based on 12 of 14 AMS ${ }^{14} \mathrm{C}$ determinations performed at the Lawrence Livermore National Laboratory Center for Accelerator Mass Spectrometry on the total organic carbon (TOC) fraction of cored sediment (Table 2, Fig. 2). Small aliquots of sediment $(20-50 \mathrm{mg})$ were rinsed several times in an ultrasonic bath with deionized water to remove salts and also with $0.1 \mathrm{~N} \mathrm{HCl}$ in order to remove soluble carbonate from the sediment. The samples were then dried at $50^{\circ} \mathrm{C}$ in a vacuum oven. The procedure used for oxidation of bulk organic matter in pretreated sediment and subsequent reduction of $\mathrm{CO}_{2}$ to filamentous graphite for AMS assay is described in Vogel et al. (1987).

An age model for PLC92B was obtained by fitting a thirddegree polynomial (Fig. 2) to the ${ }^{14} \mathrm{C}$ age-depth data set (Table 2). Two samples (CAMS 10640 and 11989) were excluded from the fit. We believe the relatively young ages of these samples may derive from incorporation of plant roots that penetrated the sediment during a lowstand that occurred after $26,500{ }^{14} \mathrm{C}$ yr B.P.

${ }^{18} \mathrm{O}$ data were obtained for PLC92B samples in order to estimate lake size at the time of deposition of the tephra layers (Benson et al., 1996). The isotopic value of Pyramid Lake $\left(\delta^{18} \mathrm{O}_{\mathrm{L}}\right)$ at any particular instant represents a balance between isotopically light water entering the lake as streamflow discharge and on-lake precipitation $\left(V_{\mathrm{d}, \mathrm{p}}\right)$ and isotopically light water leaving the lake as evaporation $\left(V_{\mathrm{e}}\right)$. When $V_{\mathrm{d}, \mathrm{p}}>V_{\mathrm{e}}$, lake level rises and $\delta^{18} \mathrm{O}_{\mathrm{L}}$ decreases; when $V_{\mathrm{e}}>$ $V_{\mathrm{d}, \mathrm{p}}$, lake level declines and $\delta^{18} \mathrm{O}_{\mathrm{L}}$ increases. When $V_{\mathrm{e}}=$ $V_{\mathrm{d}, \mathrm{p}}$, lake level remains constant and $\delta^{18} \mathrm{O}_{\mathrm{L}}$ increases/decreases until a steady state is achieved. Thus, the rate of change of $\delta^{18} \mathrm{O}_{\mathrm{L}}$ is a function of the rate of change in lake volume; the greater the rate of change in volume, the greater the excursion in $\delta^{18} \mathrm{O}_{\mathrm{L}}$.

When Pyramid Lake overflows, $\delta^{18} \mathrm{O}_{\mathrm{L}}$ is primarily a function of the outflow:inflow ratio. When the residence time of water in the Pyramid Lake subbasin approaches zero, its $\delta^{18} \mathrm{O}_{\mathrm{L}}$ value approaches the $\delta^{18} \mathrm{O}$ value of inflow $(\sim-10.5 \%$ ). Calcite precipitated from a $15^{\circ} \mathrm{C}$ lake in which the outflow:inflow ratio approaches unity would have a $\delta^{18} \mathrm{O}$ value of $\sim 23.0 \%$ o (VSMOW). ${ }^{3}$ Under steady-state conditions, the

\footnotetext{
${ }^{3}$ These results were obtained assuming that the $\delta^{18} \mathrm{O}$ value of Truckee River water was relatively constant $(-10.5 \%)$ throughout the period of interest and that the combined equilibrium/kinetic fractionation factor during evaporation had a value of $\sim-13.5 \%$ (Benson and White, 1994). Thus,
}

$\delta^{18} \mathrm{O}$ value of a hydrologically closed Pyramid Lake is highly enriched; e.g., calcite precipitated from a $15^{\circ} \mathrm{C}$ lake would have an $\delta^{18} \mathrm{O}$ value of $\sim 36.5 \%$.

Continuous 5-cm-thick samples were taken from the core, freeze-dried, and homogenized. The $\delta^{18} \mathrm{O}$ values of the total inorganic carbon (TIC) fraction were obtained in the following manner. Bulk samples were roasted in vacuo at $380 \pm$ $10^{\circ} \mathrm{C}$ for $1 \mathrm{hr}$. Each sample was reacted individually for 10 min at $75^{\circ} \mathrm{C}$ with $100 \% \mathrm{H}_{3} \mathrm{PO}_{4}$. Evolved $\mathrm{CO}_{2}$ was purified on a Kiel Automated Carbonate Extraction Device, ${ }^{4}$ introduced directly into a Finnigan MAT 251 triple collecting mass spectrometer, and analyzed for stable oxygen isotopes. Isotopic ratios of the samples were compared to a standard reference gas and the differences reported in standard delta $(\delta)$ notation. Isotopic compositions of analyzed samples were normalized to a best-fit curve derived from repeated analyses of three NBS standards. Data from samples with transducer pressures $<150 \mu$ and sample voltages $<0.5 \mathrm{~V}$ were discarded. All samples that had anomalously high or low isotopic values were rewashed and rerun. The reported precision for $\delta^{18} \mathrm{O}$ is $\pm 0.10 \%$; however, this value does not indicate the reproducibility of the isotopic data; i.e., the mean and standard deviation of the differences between 103 sample pairs was significantly larger $(0.34 \pm 0.37 \%)$.

The isotopic composition of liquid and solid samples have been expressed as delta $\left(\delta_{\mathrm{x}}\right)$ values, defined as

$$
\delta_{\mathrm{x}}=\frac{R_{\mathrm{x}}-R_{\mathrm{std}}}{R_{\mathrm{std}}} \times 1000,
$$

where $R_{\mathrm{x}}$ represents the ${ }^{18} \mathrm{O} /{ }^{16} \mathrm{O}$ ratio of a sample and $R_{\text {std }}$ is the corresponding ratio in a standard. The standard for ${ }^{18} \mathrm{O} /{ }^{16} \mathrm{O}$ of a water sample is Vienna standard mean ocean water (VSMOW); the standard for ${ }^{18} \mathrm{O} /{ }^{16} \mathrm{O}$ of a solid sample is Vienna Peedee belemnite (VPDB). The relationship between the two standards is given by

$$
\delta^{18} \mathrm{O}_{\mathrm{VPDB}}=\left(\delta^{18} \mathrm{O}_{\mathrm{VSMOW}}-30.91\right) / 1.0391 .
$$

\section{RESULTS AND DISCUSSION}

\section{Radiocarbon Age Control for the THS and Wono Tephras}

The ${ }^{14} \mathrm{C}$ ages of the THS and Wono layers found at the Wizards Cove site were estimated using the age-depth plot of PLC92B (Fig. 2). Our estimated ${ }^{14} \mathrm{C}$ age of the THS layer $\left(23,200 \pm 300{ }^{14} \mathrm{C}\right.$ yr B.P. $)$ is nearly identical to, but more precise than, the estimate $(23,400 \pm 430$ to $1720 \mathrm{yr}$ B.P.)

the steady-state $\delta^{18} \mathrm{O}$ value of a hydrologically closed Pyramid Lake should be $\sim 3.0 \%$. At $15^{\circ} \mathrm{C}$, the calcite-water fractionation factor is $33.5 \%$ (O'Neil et al., 1969).

${ }^{4}$ Use of trade names in this report does not imply endorsement by the U.S. Geological Survey or the Lawrence Livermore National Laboratory. 
TABLE 1

Electron Microprobe Analyses of Volcanic Glass Shards Separated from the Trego Hot Springs and Wono Tephra Layers ${ }^{a}$

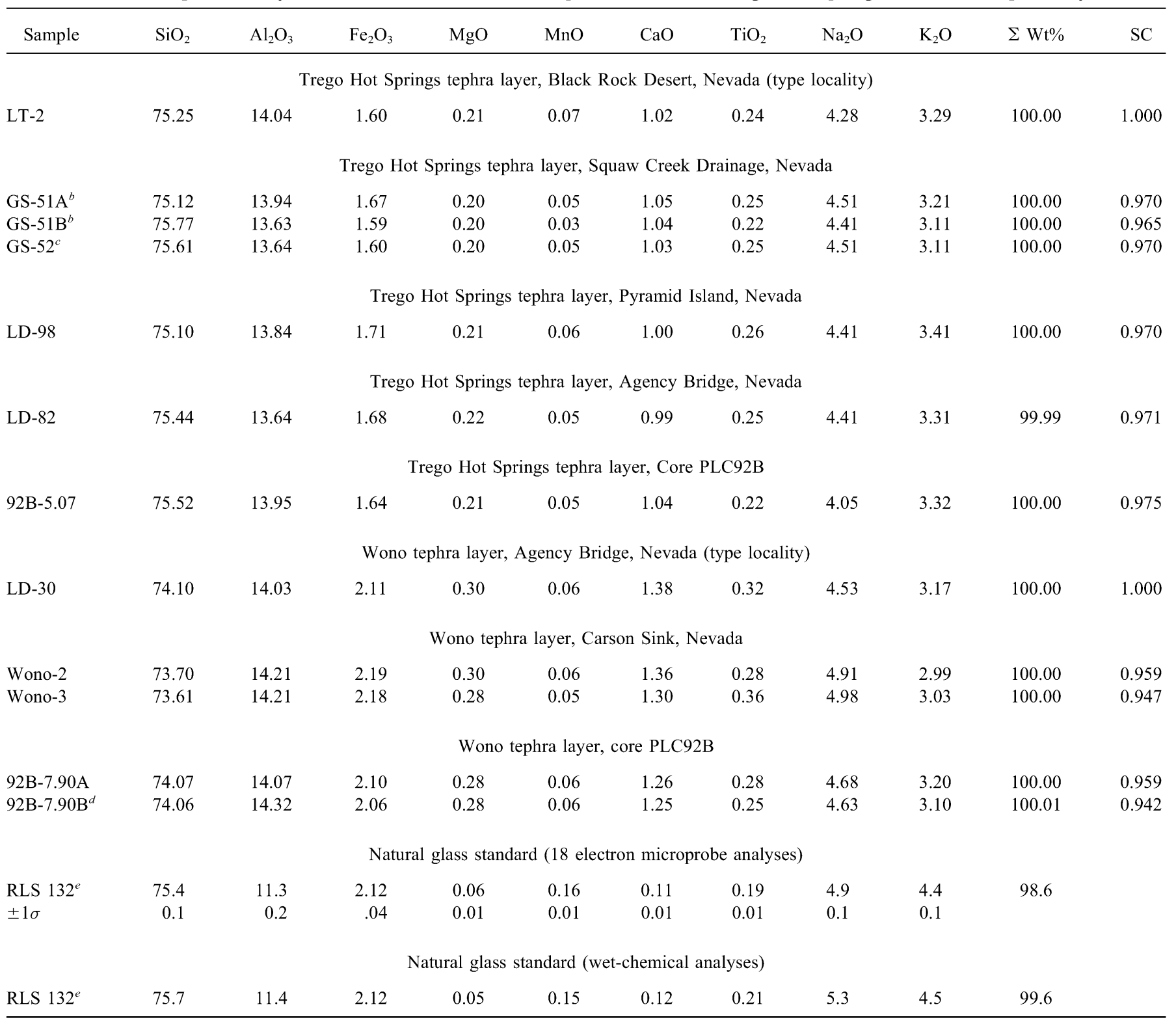

${ }^{a}$ Values represent an average of $\sim 20$ analyses of individual glass shards from each sample (in oxide weight percentage). The total have been recalculated to a $100 \%$ fluid-free basis. Replicates of a homogeneous natural glass standard (RLS 132) provide an approximation of analytical precision and accuracy. A value of one for the similarity coefficient (SC) equals a perfect match between the chemical compositions of two tephra layers.

${ }^{b}$ Upstream locality.

${ }^{c}$ Downstream locality.

${ }^{d}$ This sample was pushed from $7.90 \mathrm{~m}$ to $8.45 \mathrm{~m}$ in an attempt to core through the Wono tephra layer.

${ }^{e}$ Iron reported as $\mathrm{FeO}$.

of Davis (1983); however, our estimated age of the Wono layer $(27,300 \pm 300 \mathrm{yr}$ B.P. $)$ is $3000 \mathrm{yr}$ older than the original estimate of Davis (1983). Broecker and Walton (1959) showed that modern organic matter formed in Pyramid Lake has normalized ${ }^{14} \mathrm{C}$ ages of $\sim 600 \mathrm{yr}$. If the relatively shallow lakes in which the tephra layers were depos- ited had this same reservoir age, the THS and Wono tephra layers were actually deposited $\sim 22,600$ and $\sim 26,700{ }^{14} \mathrm{C}$ yr B.P. A linear fit to the ${ }^{14} \mathrm{C}$ and ${ }^{230} \mathrm{Th} /{ }^{234} \mathrm{U}$ data for marine corals yields reservoir-corrected calibrated ages for the THS and Wono tephra layers of $\sim 27,000$ and $\sim 32,100$ cal yr B.P. (Bard et al., 1990, 1993, 1996; Edwards et al., 1993). 
TABLE 2

Radiocarbon Dates of the Acid-Leached Total Organic Fraction of Samples from Core PLC92B

\begin{tabular}{lcc}
\hline Laboratory No. & Depth $(\mathrm{m})$ & Age $\left({ }^{14} \mathrm{C}\right.$ yr B.P. $)$ \\
\hline CAMS-10638 & $0.05-0.10$ & $13,080 \pm 60$ \\
CAMS-10781 & $1.05-1.10$ & $14,710 \pm 70$ \\
CAMS-10782 & $2.00-2.05$ & $17,450 \pm 100$ \\
CAMS-10783 & $3.00-3.05$ & $19,880 \pm 130$ \\
CAMS-10639 & $4.45-4.50$ & $22,420 \pm 110$ \\
CAMS-10663 & $6.30-6.35$ & $24,800 \pm 150$ \\
CAMS-10640 & $8.55-8.60$ & $28,240 \pm 190$ \\
CAMS-10641 & $9.65-9.70$ & $29,550 \pm 230$ \\
CAMS-10642 & $11.35-11.40$ & $26,550 \pm 180$ \\
CAMS-11989 & $11.45-11.50$ & $28,240 \pm 240$ \\
CAMS-10784 & $11.90-11.95$ & $32,410 \pm 420$ \\
CAMS-10643 & $13.60-13.65$ & $34,940 \pm 470$ \\
CAMS-10644 & $15.25-15.30$ & $36,710 \pm 500$ \\
CAMS-10655 & $17.30-17.35$ & $40,920 \pm 960$ \\
\hline
\end{tabular}

The ${ }^{14} \mathrm{C}$ ages of TOC immediately above, below, and within the THS layer at the Pyramid Island site are appreciably younger than the age of the THS layer determined from PLC92B. At the Pyramid Island site (Fig. 1), sediment immediately overlying the THS layer has an age of 22,240 \pm $190{ }^{14} \mathrm{C}$ yr B.P. (CAMS-10993). Organic carbon from within the tephra layer has a ${ }^{14} \mathrm{C}$ age of $\sim 18,900 \pm 210 \mathrm{yr}$ B.P. (CAMS-10994); sediment from immediately below the THS layer has an age of $21,300 \pm 100$ yr B.P. (CAMS-10992;

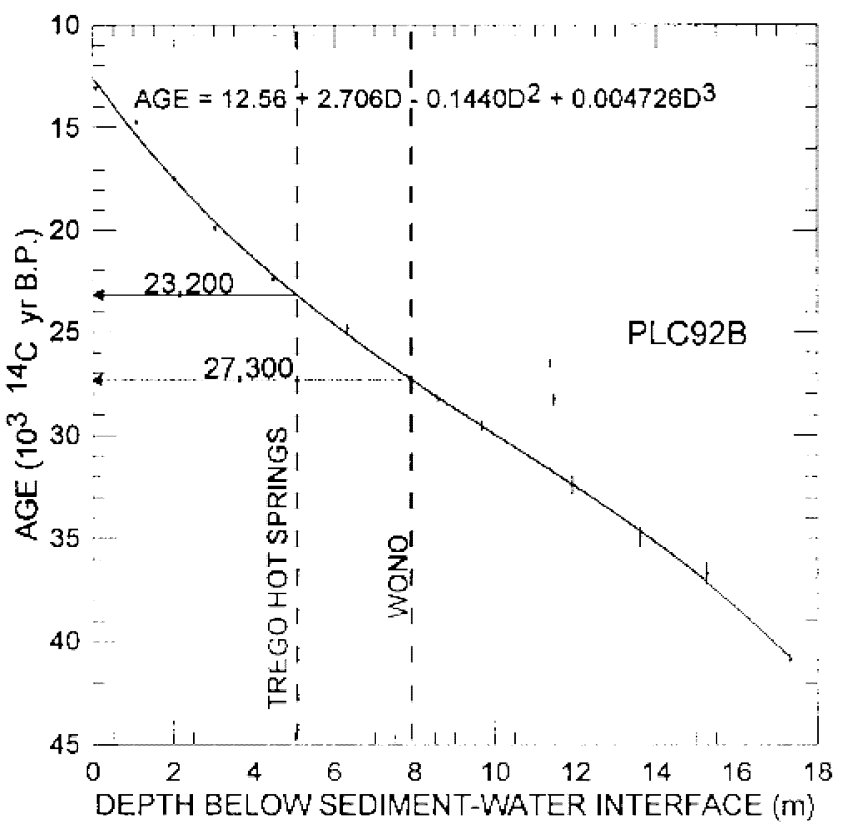

FIG. 2. Age model for core PLC92B and the position of the Trego Hot Springs and Wono tephras within the core. All radiocarbon ages are in uncalibrated ${ }^{14} \mathrm{C}$ yr B.P.
TABLE 3

Radiocarbon Dates of Tufa and the Acid-Leached Total Organic Carbon (TOC) Fraction of Samples from the Pyramid Island Site

\begin{tabular}{llcc}
\hline Laboratory No. & Sample type & Depth $(\mathrm{m})$ & Age $\left({ }^{14} \mathrm{C}\right.$ yr B.P. $)$ \\
\hline CAMS-5909 & Tufa & $0.84-0.86$ & $10,560 \pm 70$ \\
CAMS-5910 & Tufa & $0.84-0.86$ & $10,670 \pm 70$ \\
CAMS-5912 & Tufa & $0.84-0.86$ & $10,920 \pm 100$ \\
CAMS-5911 & Tufa & $0.84-0.86$ & $10,960 \pm 80$ \\
CAMS-10995 & TOC & $0.86-0.90$ & $17,990 \pm 140$ \\
CAMS-6429 & TOC & $0.86-0.90$ & $18,180 \pm 300$ \\
CAMS-10993 & TOC & $1.10-1.14$ & $22,240 \pm 190$ \\
CAMS-10994 & TOC in tephra & $1.14-1.15$ & $18,900 \pm 210$ \\
CAMS-10992 & TOC & $1.15-1.19$ & $21,300 \pm 100$ \\
\hline
\end{tabular}

Table 3). We suspect that the ${ }^{14} \mathrm{C}$ data from the Pyramid Island site reflect contamination with organic carbon from plants that grew at the site after it was subaerially exposed. In the arid environment of the Great Basin, roots of plants such as rabbit brush (Chrysothamnus) and sage (Artemisia) frequently penetrate from one to several meters below the sediment surface (Foxx and Tierney, 1986). Living roots as much as $1 \mathrm{~cm}$ in diameter were observed penetrating the THS layer and underlying sediments. The ${ }^{14} \mathrm{C}$ data (especially the young ${ }^{14} \mathrm{C}$ age of organic carbon extracted from the tephra layer) suggest that the layer acted as a perched aquifer, supplying water to plants whose root systems penetrated the sediments overlying the tephra layer and the layer itself. These data dictate caution when using ${ }^{14} \mathrm{C}$ measurements of the TOC fraction of subaerially exposed sediments to establish lake-level chronologies.

\section{Oxygen-Isotope Evidence of Lake-Level Variation during \\ Deposition of THS and Wono Tephra Layers}

The $\delta^{18} \mathrm{O}$ record for Lake Lahontan between 30,000 and $20,000{ }^{14} \mathrm{C}$ yr B.P. (Fig. 3) shows a considerable degree of variability. The THS tephra layer was deposited during a maxima in $\delta^{18} \mathrm{O}$; i.e., Pyramid Lake was probably shallow. The decreasing trend in $\delta^{18} \mathrm{O}$ values between 22,000 and 21,000 yr B.P. reflects the increase in lake volume documented in the tufa-based lake-level chronology of Lake Lahontan (Fig. 4). The $\delta^{18} \mathrm{O}$ data from PLC92B indicate that the Wono tephra was deposited in a relatively deep lake just prior to a major recession in lake level (Fig. 3). The relatively low $\delta^{18} \mathrm{O}$ value $(28.7 \%$ ) indicates that Pyramid Lake may have been spilling across Emerson Pass sill $(1207 \mathrm{~m})$ to the Smoke Creek-Black Rock Desert subbasin at this time.

Davis's (1978) interpretation of the depositional environment of the THS layer at the downstream Squaw Creek site led him to conclude that the surface of Lake Lahontan stood above $1256 \mathrm{~m}$ at the time the ash was deposited. This conclusion is not consistent with our interpretation of the $\delta^{18} \mathrm{O}$ record from PLC92B which indicates the existence of a rela- 


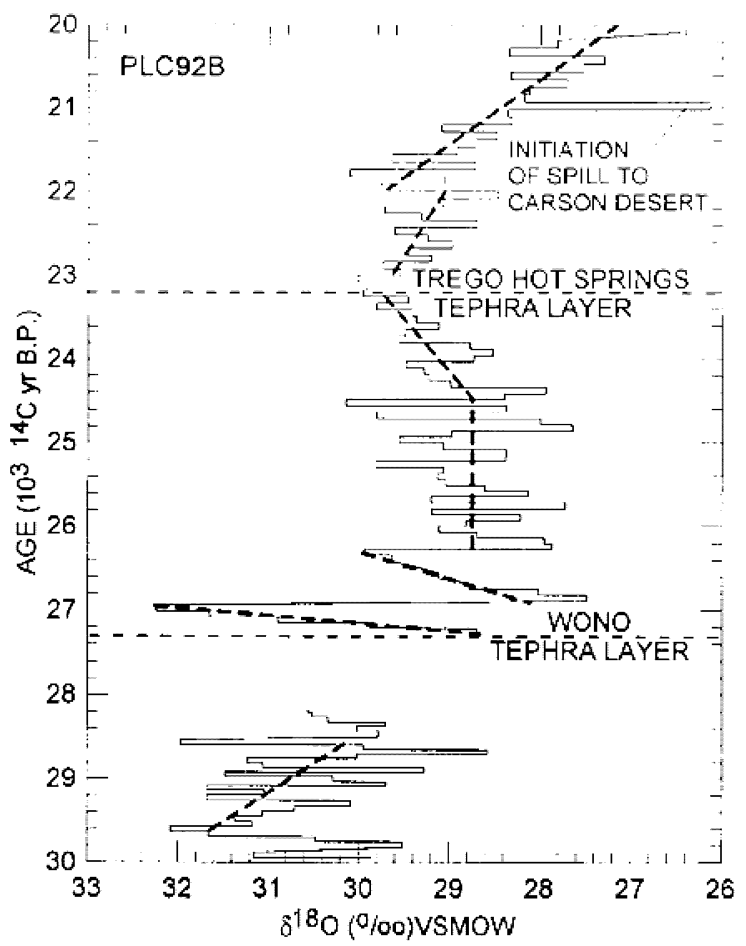

FIG. 3. Oxygen-isotope record for core PLC92B for the period 30,000 to $20,000{ }^{14} \mathrm{C}$ yr B.P. Large values of $\delta^{18} \mathrm{O}$ indicate times of shallow closedbasin conditions or low spill:input ratios in the Pyramid Lake subbasin. Heavy dashed lines indicate trends in $\delta^{18} \mathrm{O}$ values.

tively shallow lake in the Pyramid Lake subbasin at 23,200 ${ }^{14} \mathrm{C}$ yr B.P. (Fig. 3). To determine the source of this inconsistency, we studied the sediments at four sites in the Pyramid Lake and Smoke Creek-Black Rock Desert subbasins that contain one or both of the tephra layers.

\section{Sedimentological Evidence of Water Depth during Deposition of the THS and Wono Tephra Layers}

Squaw Creek. Two terraces are cut by Squaw Creek, an older, higher terrace dominated by yellowish sand and gravel and a younger, lower terrace dominated by brownish-gray silt and sand. The older terrace roughly parallels the modern Squaw Creek drainage and contains the THS layer near its base. The younger terrace contains layers of boulders and cobbles and is set within a paleovalley cut into the older terrace.

Most of the sediment in the older terrace was deposited in deltaic or wave-dominated, shallow-water environments. Deposits of deltaic silt and fine sand are dominated by rippledrift cross-lamination and muddy silt with abundant softsediment deformation features indicative of lower delta foreset or toeset deposits. Steep delta foresets are composed of medium-to-coarse sand. Wave-formed sand and gravel deposits occur as northward-dipping tabular sets (bars) and thin beds with oscillatory ripple structures or well-sorted pebbles. Horizons disrupted by root casts occur intermittently beneath wave-formed deposits commonly associated with stream-deposited sand and gravel.

We examined two prominent exposures equivalent to those reported by Davis (1983). The THS layer occurs near the base of the downstream exposure of the older terrace $\left(40^{\circ} 47.541^{\prime} \mathrm{N}, 119^{\circ} 30.563^{\prime} \mathrm{W}\right)$ which is $\sim 15 \mathrm{~m}$ high. The basal $0.75 \mathrm{~m}$ of this exposure consists of sandy deposits, reflecting the upper part of a steep deltaic foreset overlain by cross-bedded fluvial topset sands (Figs. 5 and 6A). The cross-bedded topset sands are overlain by nearly $1 \mathrm{~m}$ of thin lenticular beds of sand and pebbly sand interbedded with gray sandy clays, all heavily disrupted by sediment-filled root casts. The sand beds typically display planar lamination, imbricate pebble layers and, rarely, decimeter-scale tabular sets. These features are interpreted as indicating a change from large streams that deposited Gilbert-type deltas to small flashy streams that cut across heavily vegetated, marshy floodplains. The sandy muds lack internal bedding, have abundant sediment-filled root casts and diffuse contacts that

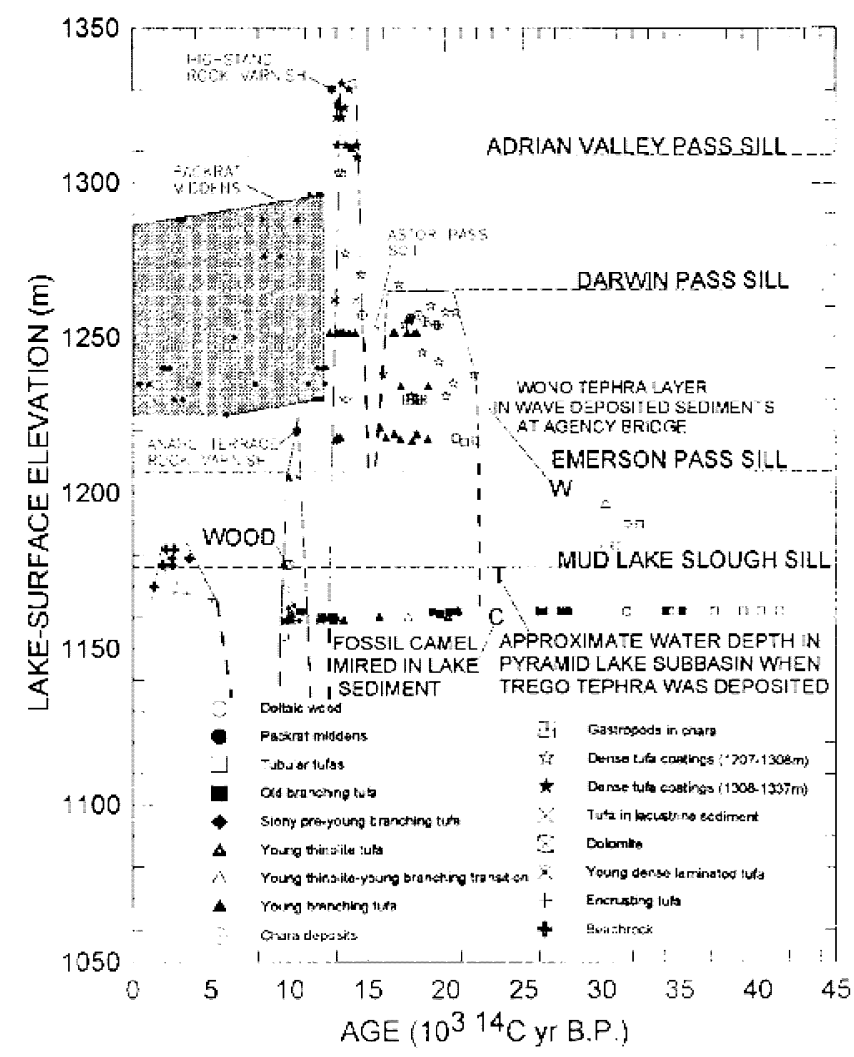

FIG. 4. Tufa-based Lahontan lake-level record. For a detailed description of the types of samples used in constructing this figure, see Benson et al. (1995). The samples from 1160 to $1165 \mathrm{~m}$ came from tufa mounds along the shore Pyramid Lake. Many of these samples may have formed in relatively deep water; therefore, their elevations represent minimum estimates of lake level at the time of their deposition. 
A

DOWNSTREAM SECTION

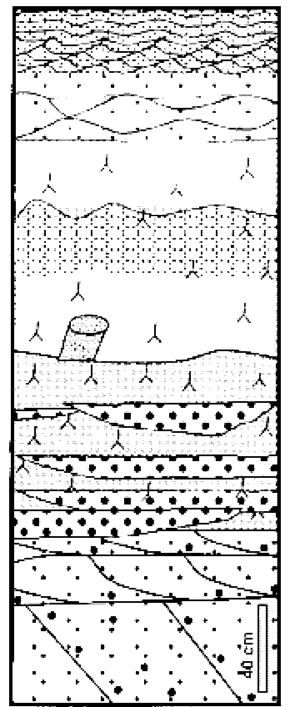

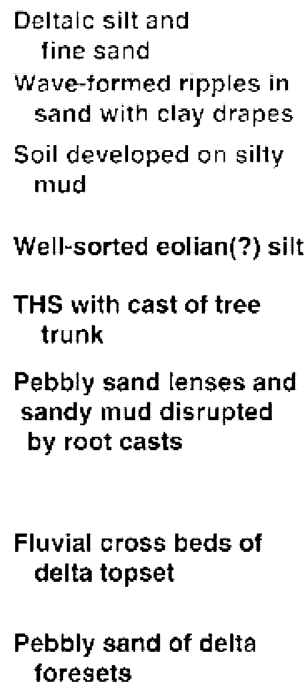

B

UPSTREAM SECTION

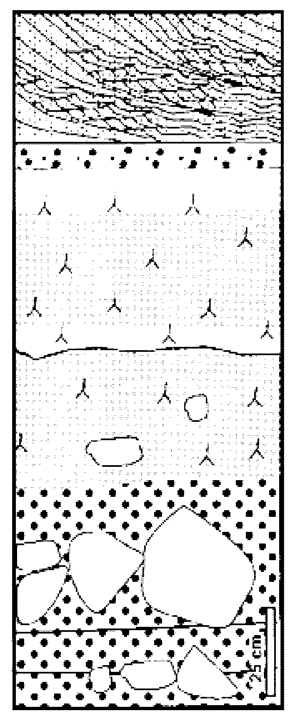

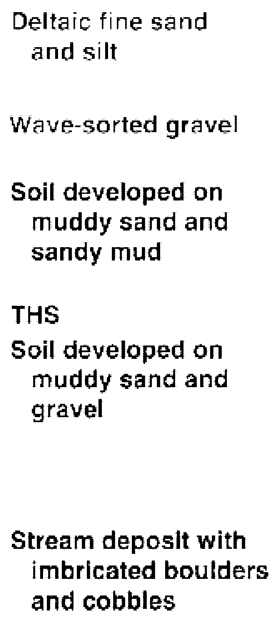

FIG. 5. Stratigraphic sections of deposits immediately adjacent to the THS tephra layer at the downstream (A) and upstream (B) exposures of the older terrace along Squaw Creek, Nevada.

cross-cut the stratification of underlying sand layers (Fig. 6B). These features reflect soil-forming processes. The THS layer overlies the gray sandy muds and pebbly sand lenses. Large sediment-filled cylinders are believed to be the casts of tree trunks that grew prior to deposition of the THS layer (Fig. 6A).

At this site, the THS is a pure white airfall ash that grades upward into a structureless, well-sorted siliciclastic silt. The sorting indicates that the silt is eolian in origin. The silt layer is overlain by poorly sorted, brownish, silty-to-sandy mud that contains abundant sediment-filled, oxide-stained root casts, polygonal columnar parting, and horizons with higher clay content that show rounded columnar vertical features. These features indicate that the silty-to-sandy mud is a soil that has been overprinted on the eolian silt. The silty mud is sharply capped by a pebbly sand containing oscillatory ripple structures and clay drapes. The pebbly sand is overlain by a silt and fine sand that display ripple-drift cross lamination. The coarse sand was deposited by waves during a transgression and the silt and fine sand were deposited in deltaic toesets.

The upstream outcrop of the older terrace $\left(40^{\circ} 47.542^{\prime} \mathrm{N}\right.$, $119^{\circ} 30.667^{\prime} \mathrm{W}$ ) is smaller and poorly exposed. The sediments underlying the THS layer include a basal, flat-bedded pebbly sand with scattered boulders and cobbles displaying imbricate stacking and shadow fabrics (Figs. 5 and 6C). The pebbly sand is overlain by nonbedded muddy sand and sandy mud containing scattered pebbles and cobbles. Sedimentfilled root casts are common in the muddy layer which displays poorly developed polygonal parting. This succession of sedimentary features suggests a change from active highenergy stream deposition to soil-forming conditions. The THS layer lies within the muddy deposits. Above the THS layer, the muddy deposits show better-developed polygonal parting and some carbonate accumulation within root casts. The muddy deposits are sharply overlain by a thin layer of wave-deposited, well-sorted gravel, which in turn is overlain by fine sand and silt with ripple-drift cross-bedding that defines low-angle foresets. This latter succession is interpreted to have formed during a transgression of Lake Lahontan. The transgressive wave deposits were followed by shallowwater deposition of deltaic foresets.

In contrast to the interpretation of Davis (1983), we conclude that the outcrops along Squaw Creek indicate that the THS layer was deposited subaerially, following regression of Lake Lahontan. The interval of subaerial exposure lasted long enough to produce poorly developed soil horizons and the growth of $20-\mathrm{cm}$-diameter trees. The soil features superimposed on the THS layer indicate that a prolonged period of subaerial exposure also occurred after deposition of the THS layer.

Agency Bridge. Further insight regarding the level of Lake Lahontan during deposition of the Wono layer is provided by sediments from the Agency Bridge site (Fig. 1). At this site, the Wono layer (1203 m) occurs within a wavesorted sand composed of reworked ostracodes, snails, and charophytes. The sand was deposited in no more than a few meters of water. A 10 -cm-thick layer of eolian silt occurs $\sim 15 \mathrm{~cm}$ above the Wono layer. At the time the Wono layer 

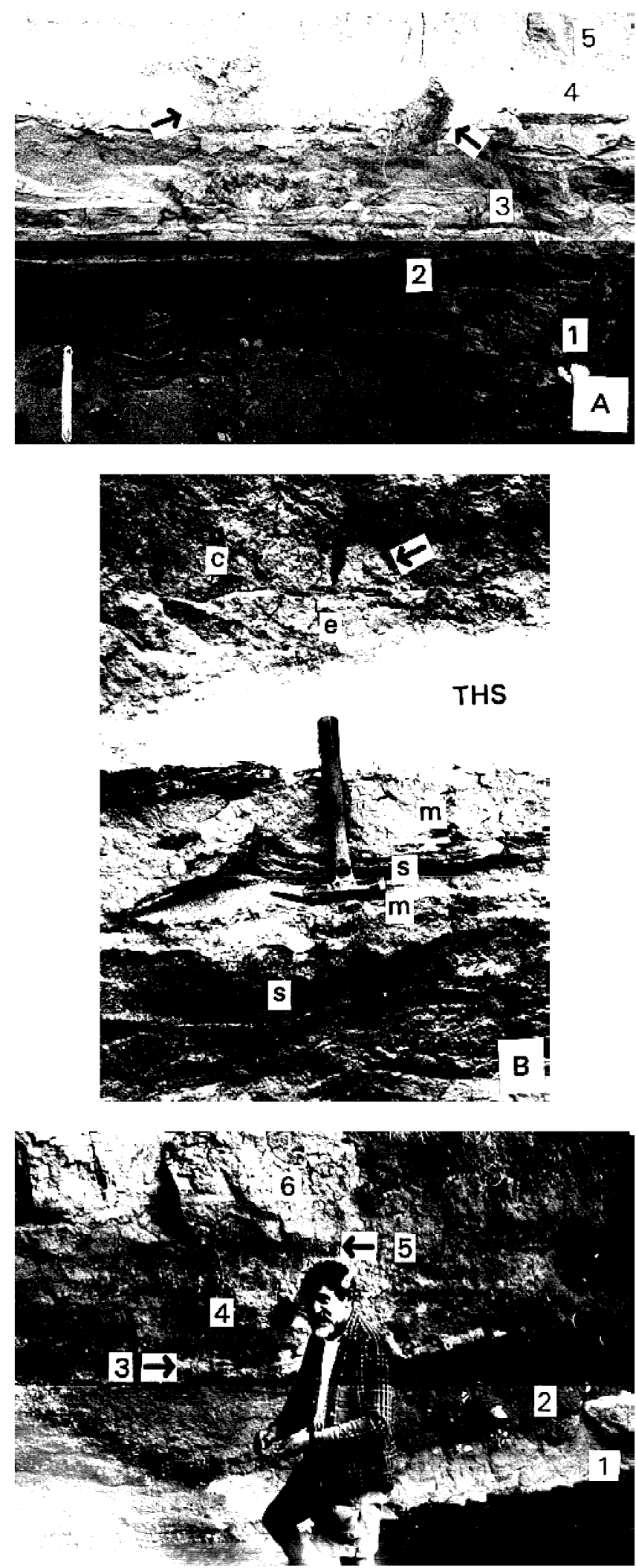

FIG. 6. Photos of sedimentary deposits immediately adjacent to the THS tephra layer at the downstream exposure (A and B) and the upstream exposure (C) of the older terrace along Squaw Creek. (A) Numbers indicate was deposited, lake level was probably controlled by spill over Emerson Pass sill (1207 m).

The Wono layer is not found in the Truckee River canyon upstream from Agency Bridge. Stratigraphic correlations along outcrop exposed in the canyon show a soil horizon correlative to the Wono layer. These observations indicate that lake level was receding when the Wono layer was deposited at Agency Bridge and that subaerial exposure of the site occurred soon after the layer was deposited.

Wizards Cove. In core PLC92B, taken from Wizards Cove (Fig. 1), a silty clay with flat (1- to 5-mm-thick), graded laminae that have been disturbed by small, mostly horizontal burrows lies below the THS layer. The THS layer itself occurs within a silty clay that contains abundant ostracodes and randomly oriented, sand-filled burrows (Fig. 7). These sedimentary features indicate that the THS layer was deposited in a relatively shallow, well-oxygenated environment; i.e., the lake was no more than a few tens-of-meters deep. An increasing number of wave-formed sand lenses, containing reworked ostracode valves occur above the THS layer. This suggests that the THS layer was deposited during a recession in lake level; i.e., oxygen-depleted deep-water conditions gave way progressively to shallow-water conditions that enabled wave suspension and reworking of bottom sediments.

In PLC92B, the Wono layer resides within a sequence of thickly laminated, silty clay similar to that found below the THS layer (Fig. 7). Several centimeters above the Wono Layer, the silty clay is burrowed and contains ostracode fragments. Patches of ostracode-rich clay are stained orange and contain small carbonaceous cylinders (root casts). A thin horizon of graded sand beds overlies the ostracode-rich clay. These sedimentary features suggest that the Wono layer was deposited during a recession in lake level and that the Wizards Cove site was subaerially exposed after deposition of the layer. A 3.6\% increase in $\delta^{18} \mathrm{O}$ between 27,300 and $27,000{ }^{14} \mathrm{C}$ yr B.P. also indicates a large and abrupt decrease in lake size after deposition of the Wono layer (Fig. 3).

Pyramid Island. Unlike the Wizards Cove site, the Pyramid Island site (Fig. 1) has been subaerially exposed since

the deltaic foreset [1], topset fluvial sand [2], interbedded pebbly sand lenses and sandy clay [3], THS layer [4], and eolian slit [5] which shows faint development of columnar parting near top of photo. Arrows, sediment-filled casts of tree trunks overlain by THS layer. Scale bar is $50 \mathrm{~cm}$ long. (B) Detail of deposits above and below the THS (white). Below the THS, sandy mud $[\mathrm{m}]$ layers are interbedded with pebbly sand [s]. Note how mud crosscuts stratification in underlying sand units. The contact between the eolian silt [e] and THS layer is gradational. The slit is muddier higher in the stratigraphic sequence, becoming a polygonally cracked poorly sorted clay [c]. Rounded tops of columnar features in clay-rich zone (arrows) are interpreted as features of soil B horizon. Hammer is $30 \mathrm{~cm}$ long. (C) Upstream exposure showing basal pebbly sand with boulders [1], nonbedded muddy sand with scattered pebbles and cobbles [2], the THS layer [3], muddy sand with carbonate-rich root casts [4], wave-sorted gravel [5], and deltaic sand and with ripple-drift cross-lamination [6]. Outcrop is about $2 \mathrm{~m}$ high. 


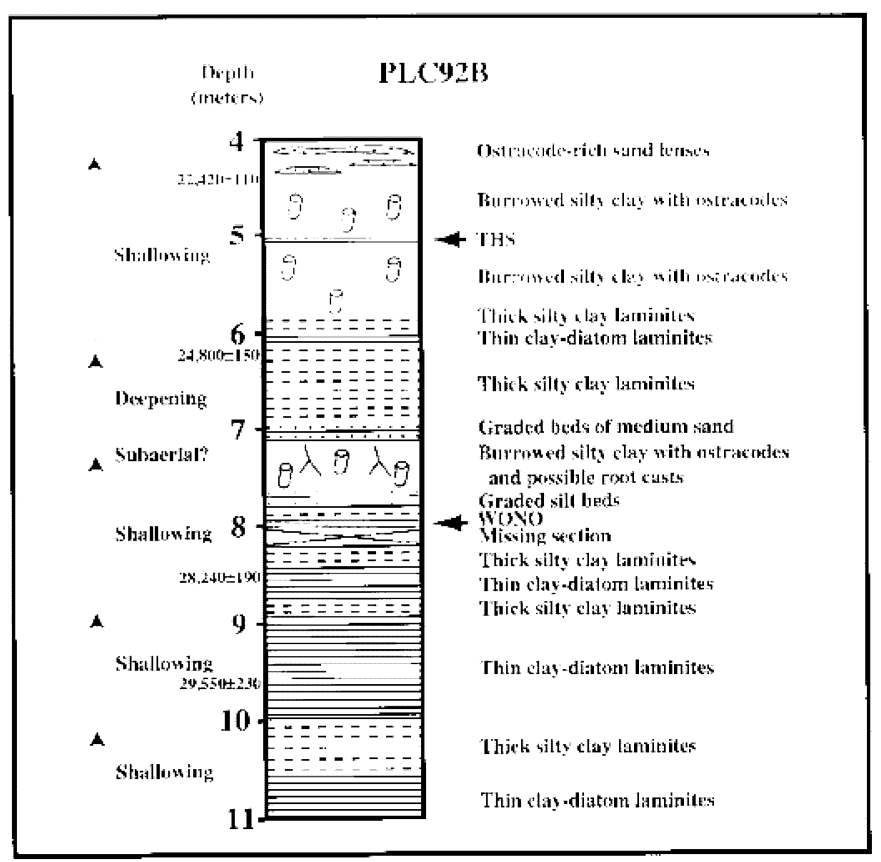

FIG. 7. Stratigraphic section of PLC92B at Wizards Cove 4 to $7 \mathrm{~m}$ below sediment-water interface. Arrows on left side of section indicate direction of lake depth variation interpreted from sedimentary features. Locations of samples for radiocarbon age dates are shown at left of section.

about 1950. The tufa layer at this site (Fig. 8A) formed during the last Pleistocene maxima of Lake Lahontan (Fig. 4). The oscillation in lake level that occurred between 11,000 and 10,000 yr B.P. may have caused erosion of Holocene and late Pleistocene sediment $\left(<12,900{ }^{14} \mathrm{C}\right.$ yr B.P.), presently missing from the Wizards Cove site. Below the tufa layer, a wedge-shaped layer of sand, containing a basal gravel, overlies $3.75 \mathrm{~m}$ of fine-grained lake sediment. The THS layer lies $1.15 \mathrm{~m}$ below the contact with the basal gravel and a well-sorted sand underlies the fine-grained sediment.

At the Pyramid Island site, the THS layer occurs within a clay that contains abundant ostracodes, random sand-filled burrows, and wave-formed sand lenses composed of reworked ostracodes and snails (Fig. 8B). These features indicate that the THS layer was deposited in a lake that was no more that a few tens-of-meters deep. Initiation of lake-level recession is indicated by a thin-bedded silty clay located $\sim 10 \mathrm{~cm}$ below the THS layer. The clay contains flat ostracode laminae probably deposited by storm-wave initiated turbidites.

At the Pyramid Island site (Fig. 8B), the Wono layer lies within a silty mud sequence similar to that found below the THS layer. The two tephra layers are separated by a zone of wave-formed sand lenses that overlie sand-filled polygonal cracks that penetrate 20 to $30 \mathrm{~cm}$ into a burrowed silty clay. These features indicate that subaerial exposure occurred between deposition of the two tephra layers. Only $0.40 \mathrm{~m}$ of sediment separates the tephra layers at this site (Fig. 8B), whereas $2.83 \mathrm{~m}$ of sediment separates them in PLC92B. The sediment interval separating the two tephra layers at PLC92B contains a continuous record of lake level lowering; however, the evidence of the lake-level recession is missing from
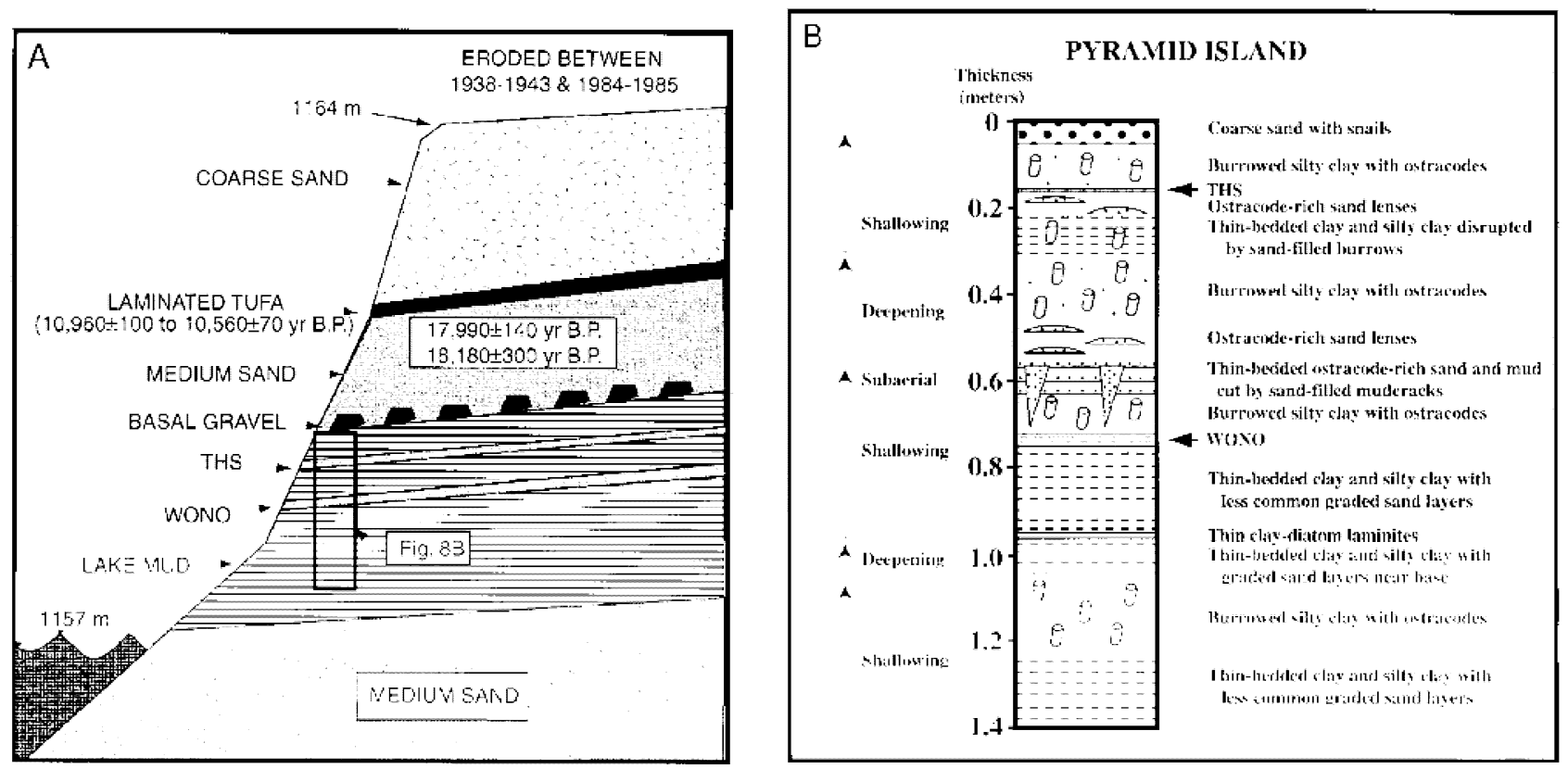

FIG. 8. (A) Schematic stratigraphic section of the Pyramid Island site (site JOD 11 of Davis, 1978); detail of section enclosed by rectangle shown in Fig. 8B. (B) Detailed section of clay-rich deposits at Pyramid Island. Arrows indicate relative changes of lake depth interpreted from sedimentary features. 
the Pyramid Island site; i.e., subaerial features are directly superimposed on deep-water sediments. These observations suggest that the regressive sequence was removed from the Pyramid Island site by deflation during subaerial exposure. This implies that sedimentation at the Pyramid Island site was not constant between 34,000 and 23,000 yr B.P. as Davis (1978) assumed in his estimate of the age of the THS layer.

\section{SUMMARY}

Observations of sedimentologic features at the Wizards Cove and Pyramid Island sites indicate that the THS was deposited in a relatively shallow lake, the surface elevation of which was probably constrained by spill to the Winnemucca Lake subbasin. Relatively high values of $\delta^{18} \mathrm{O}$ were recorded in the carbonate fraction of Wizards Cove sediment at the time the THS layer was deposited, supporting the concept of a shallow-water environment. The Wono tephra layer was deposited in a deeper lake for which the surface elevation was constrained by spill to the Smoke CreekBlack Rock Desert subbasin. Both sedimentologic features and $\delta^{18} \mathrm{O}$ values indicate that an abrupt decrease in lake level occurred soon after deposition of the Wono layer.

\section{ACKNOWLEDGMENTS}

Radiocarbon analyses were performed in part under the auspices of the U.S. Department of Energy by Lawrence Livermore National Laboratory under Contract W-7405-ENG-48. Other studies reported here were funded by the Global Change Program of the U.S. Geological Survey. We thank Tim Lowenstein of SUNY-Buffalo and Fred Paillet, Sarah Spaulding, and John Flager of the U.S. Geological Survey for their comments on versions of the manuscript.

\section{REFERENCES}

Bard, E., Hamelin, B., Fairbanks, R., and Zindler, A. (1990). Calibration of the ${ }^{14} \mathrm{C}$ timescale over the past 30,000 years using mass spectrometric $\mathrm{U}-\mathrm{Th}$ ages from Barbados corals. Nature 345, 405-410.

Bard, E., Arnold, M., Fairbanks, R. G., and Hamelin, B. (1993). ${ }^{230} \mathrm{Th}-{ }^{234} \mathrm{U}$ and ${ }^{14} \mathrm{C}$ ages obtained by mass spectrometry on corals. Radiocarbon 35 , 191-199.

Bard, E., Hamelin, B., Arnold, M., Montaggioni, L., Cabioch, G., Faure,
G., and Rougerie, F. (1996). Deglacial sea-level record from Tahiti corals and the timing of global meltwater discharge. Nature 382, 241-244.

Benson, L. V., Currey, D. R., Dorn, R. I., Lajoie, K. R., Oviatt, C. G., Robinson, S. W., Smith, G. I., and Stine, S. (1990). Chronology of expansion and contraction of four Great Basin lake systems during the past 35,000 years. Palaeogeography, Palaeoclimatology, Palaeoecology 78, 241286.

Benson, L. V., and White, J. W. C. (1994). Stable isotopes of oxygen and hydrogen in the Truckee River-Pyramid Lake surface-water system. 3. Source of water overlying Pyramid Lake. Limnology and Oceanography 39, 1945-1958.

Benson, L. V., Kashgarian, M., and Rubin, M. (1995). Carbonate deposition, Pyramid Lake subbasin, Nevada. 2. Lake levels and polar jet stream positions reconstructed from radiocarbon ages and elevations of carbonates (tufas) deposited in the Lahontan basin. Palaeogeography, Palaeoclimatology, Palaeoecology 117, 1-30.

Benson, L. V., White, L. D., and Rye, R. O. (1996). Carbonate deposition, Pyramid Lake subbasin, Nevada. 4. Comparison of the stable isotope values of carbonate deposits (tufas) and the Lahontan lake-level record. Palaeogeography, Palaeoclimatology, Palaeoecology 122, 45-76.

Berger, G. W. (1992). Dating volcanic ash by thermoluminescence. Geology 20, 11-14.

Broecker, W. S., and Walton, A. F. (1959). The geochemistry of ${ }^{14} \mathrm{C}$ in freshwater systems. Geochimica et Cosmochimica Acta 16, 15-38.

Davis, J. O. (1978). "Quaternary Tephrochronology of the Lake Lahontan Area, Nevada and California." Nevada Archeology Survey Paper 7.

Davis, J. O. (1983). Level of Lake Lahontan during deposition of the Trego Hot Springs tephra about 23,400 years ago. Quaternary Research 19, 312-324.

Edwards, R. L., Beck, J. W., Burr, G. S., Donahue, D. J., Chappell, J. M. A., Bloom, A. L., Druffel, E. R. M., and Taylor, F. W. (1993). A large drop in atmospheric ${ }^{14} \mathrm{C} /{ }^{12} \mathrm{C}$ and reduced melting in the Younger Dryas, documented with ${ }^{230} \mathrm{Th}$ ages of corals. Science 260, 962-968.

Foxx, T. S., and Tierney, G. D. (1986). Rooting patterns in the PinyonJuniper woodland. In "Proceedings Pinyon-Juniper Conference, Intermountain Research Station, Ogden UT, Reno, NV, January 13-16, 1986" (R. Everett, Ed.), pp. 69-79.

Negrini, R. M., and Davis, J. O. (1992). Dating late Pleistocene pluvial events and tephras by correlating paleomagnetic secular variation records from the western Great Basin. Quaternary Research 38, 46-59.

O’Neil, J. R., Clayton, R. N., and Mayeda, T. K. (1969). Oxygen isotope fractionation in divalent metal carbonates. Journal of Chemical Physics 51, 5547-5558.

Sarna-Wojcicki, A., Bowman, H., Meyer, C., Russell, P., Woodward, M., McCoy, G., Rowe, J., Baedecker, P., Asaro, F., and Michael, H. (1984). "Chemical Analyses, Correlations, and Ages of Upper Pliocene and Pleistocene Ash Layers of East-Central and Southern California."' U.S. Geological Survey Professional Paper 1293, pp. 1-40.

Vogel, J. S., Nelson, D. E., and Southon, J. R. (1987). ${ }^{14} \mathrm{C}$ background levels in an accelerator mass spectrometry system. Radiocarbon 29, 323-333. 